\title{
Pt Monolayers on Electrodeposited Nanoparticles of Different Compositions for Ammonia Electro-Oxidation
}

\author{
Jie Liu ${ }^{1}$, Bin Liu ${ }^{2}$, Yating $\mathrm{Wu}^{2}{ }^{2}$, Xu Chen ${ }^{2}$, Jinfeng Zhang ${ }^{3}$, Yida Deng ${ }^{3}$, Wenbin $\mathrm{Hu}{ }^{1,3}$ \\ and Cheng Zhong 1,3,*D \\ 1 Key Laboratory of Advanced Ceramics and Machining Technology (Ministry of Education), School of \\ Materials Science and Engineering, Tianjin University, Tianjin 300072, China; jieliu0109@tju.edu.cn (J.L.); \\ wbhu@tju.edu.cn (W.H.) \\ 2 State Key Laboratory of Metal Matrix Composites, Shanghai JiaoTong University, Shanghai 200240, China; \\ andycom0@sjtu.edu.cn (B.L.); tosunbear@sjtu.edu.cn (Y.W.); jjlove@sjtu.edu.cn (X.C.) \\ 3 Tianjin Key Laboratory of Composite and Functional Material, Department of Materials Science and \\ Engineering, Tianjin University, Tianjin 300072, China; jinfeng@tju.edu.cn (J.Z.); yida.deng@tju.edu.cn (Y.D.) \\ * Correspondence: cheng.zhong@tju.edu.cn; Tel.: +86-138-1692-8737
}

Received: 5 December 2018; Accepted: 19 December 2018; Published: 21 December 2018

\begin{abstract}
Pt monolayers ( $\mathrm{Pt}_{\mathrm{ML}}$ ) supported on nanoparticles with different compositions (i.e., $\mathrm{Ru}, \mathrm{Rh}, \mathrm{Pd}$, Ir, and $\mathrm{Au}$ ) were synthesized by the surface-limited redox replacement of underpotentially deposited $\mathrm{Cu}$ monolayers on nanoparticle supports. Nanoparticle supports with different compositions were directly deposited on the conducting substrate by a clean and one-step electrodeposition method with controlled deposition potential and time. The whole synthesis process of the electrode was free of surfactants, binders, capping agents and reductants, and without an additional coating process of electrocatalysts. The results show that the specific activity (SA) of $\mathrm{Pt}_{\mathrm{ML}}$ electrocatalysts depended strongly on the composition of the nanoparticle support. For example, the $\mathrm{Pt}_{\mathrm{ML}}$ supported on the Au nanoparticle exhibited 8.3 times higher SA than that supported on the $\mathrm{Ru}$ and $\mathrm{Pd}$ nanoparticles. The change in the SA of the $\mathrm{Pt}_{\mathrm{ML}}$ supported on different nanoparticles was related to the substrate-induced strain in the $\mathrm{Pt}_{\mathrm{ML}}$ resulting from the lattice mismatch between the $\mathrm{Pt}_{\mathrm{ML}}$ and the nanoparticle support. As the strain in the $\mathrm{Pt}_{\mathrm{ML}}$ changed from the tensile strain to the compressive strain, the $\mathrm{SA}$ of the $\mathrm{Pt}_{\mathrm{ML}}$ electrocatalysts decreased remarkably.
\end{abstract}

Keywords: Pt monolayer nanoparticles; electrocatalysts; ammonia oxidation; electrodeposition

\section{Introduction}

Growing concern in energy and environmental issues has stimulated considerable research on the electro-oxidation of ammonia, since it addresses both clean energy supply and removal of pollutants [1-6]. Ammonia is a carbon-free chemical energy carrier, which has a high capacity of hydrogen storage (17.7 wt.\%) and high energy density (3000 Wh $\mathrm{kg}^{-1}$ ) [1,7]. On the other hand, ammonia is an environmental pollutant and a toxic gas. Therefore, the electro-oxidation of ammonia has important applications in direct fuel cells [8-10], hydrogen production [1,11,12], ammonia decomposition in wastewaters [8,13] and electrochemical sensors for detecting ammonia [14]. Since ammonia electro-oxidation is a sluggish reaction, electrocatalysts are required to catalyze the oxidation of ammonia to $\mathrm{N}_{2}$. Among various investigated electrocatalysts, $\mathrm{Pt}$ has been acknowledged as the most effective single-component electrocatalyst for ammonia electro-oxidation [15,16]. However, it is a limited resource and has high cost which been the main obstacles for wide usage of Pt [17-20], strongly limiting the large-scale applications of ammonia electro-oxidation technologies. Therefore, 
great efforts have been paid to the development of Pt-based electrocatalysts with a high activity for ammonia electro-oxidation and simultaneously low Pt loading.

Developing $\mathrm{Pt}_{\mathrm{ML}}$ catalysts is one of the most promising strategies because of its unique advantages, such as an extremely high utilization degree of $\mathrm{Pt}$ atoms and tunable activity through the electronic and structural effects between the $\mathrm{Pt}_{\mathrm{ML}}$ and the substrate [15-18]. Adzic's group successfully developed a class of electrocatalysts consisting of a Pt ${ }_{\mathrm{ML}}$ on different metals (e.g., $\mathrm{Au}, \mathrm{Pd}, \mathrm{Rh}$, Ir, and Ru) $[15,19,20]$,

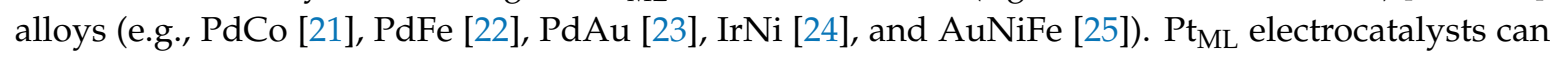
be synthesized by deposition of a $\mathrm{Cu}$ monolayer on the substrate through underpotential deposition (UPD), followed by a surface-limited replacement reaction between $\mathrm{Pt}$ ions and $\mathrm{Cu}$ monolayer [26,27]. It has been well demonstrated that a $\mathrm{Cu}$ monolayer can be replaced by a $\mathrm{Pt}_{\mathrm{ML}}$ [26]. Due to the high $\mathrm{Pt}$ utilization, the mass activity of these $\mathrm{Pt}_{\mathrm{ML}}$ electrocatalysts could be more than an order of magnitude higher than traditional all-Pt electrocatalysts $[15,18,27]$. Since the catalytic activity of the $\mathrm{Pt}_{\mathrm{ML}}$ electrocatalysts is strongly dependent on the interaction between the $\mathrm{Pt}_{\mathrm{ML}}$ and the supporting substrate $[18,19,28,29]$, it is of great interest to investigate the effect of the supporting substrate on the catalytic activity of electrocatalysts. Such studies are important for further enhancing the electrocatalytic activity of $\mathrm{Pt}_{\mathrm{ML}}$ electrocatalysts by rationally selecting or designing substrate materials. To date, a number of characteristics of substrate materials, such as composition [19,30,31], crystalline orientation $[20,21,28,31]$ and particle size $[17,21]$, have been studied as $\mathrm{Pt}_{\mathrm{ML}}$ electrocatalysts for oxygen reduction reactions and methanol electro-oxidation. However, there has so far been very limited work on $\mathrm{Pt}_{\mathrm{ML}}$ electrocatalysts for ammonia electro-oxidation [18,32]. Previous work from our group synthesized the $\mathrm{Pt}_{\mathrm{ML}}$ on an Au substrate (bulk Au electrode [32] or Au particles [18]) for ammonia electro-oxidation. These $\mathrm{Pt}_{\mathrm{ML}}$ electrocatalysts exhibited several times, to a more than 10 -fold increase, in the mass activity compared with the all-Pt electrocatalysts for ammonia electro-oxidation. It has also been found that the surface morphology of substrate material greatly influences the $\mathrm{SA}$ of $\mathrm{Pt}_{\mathrm{ML}}$ electrocatalysts [18]. Nevertheless, the effect of the composition of the substrate on the catalytic activity of $\mathrm{Pt}_{\mathrm{ML}}$ nanoparticles for ammonia electro-oxidation has remained unclear.

The purpose of the present work is to illustrate whether and how the composition of the substrate material would have an influence on the activity of the surface $\mathrm{Pt}_{\mathrm{ML}}$ nanoparticles. For practical electrocatalytic applications, it is required to support $\mathrm{Pt}_{\mathrm{ML}}$ on high surface area nanoparticles. Therefore, we investigated the activity of the $\mathrm{Pt}_{\mathrm{ML}}$ on nanoparticles with various compositions including $\mathrm{Ru}, \mathrm{Rh}, \mathrm{Pd}$, Ir and $\mathrm{Au}$. A clean, facile and one-step electrodeposition method was proposed to synthesize nanoparticles with different compositions as the supporting core, synthesized directly on the surface of conducting substrate. $\mathrm{Pt}_{\mathrm{ML}}$ was synthesized on the surface of these nanoparticles by a well-established method, consisting of Cu UPD on nanoparticles and subsequently the galvanic replacement of $\mathrm{Pt}[15,33]$. The entire synthesis process was free of any surfactants, binders, capping agents and reductants, ensuring an extremely clean surface of electrocatalysts. In addition, the electrocatalysts were synthesized directly on the conducting substrate surface, avoiding the transfer process of the electrocatalysts. This greatly decreases the uncertainty resulting from the synthesis procedures, allowing the truly comparison of the impact of the composition of the supporting core on the electrocatalytic activity of the supported $\mathrm{Pt}_{\mathrm{ML}}$. Furthermore, the relationship between the composition of the nanoparticle core of $\mathrm{Pt}_{\mathrm{ML}}$ electrocatalysts and the electrocatalytic activity for the ammonia oxidation was investigated by cyclic voltammetry (CV). To the best of our knowledge, this is the first time to report the synthesis of $\mathrm{Pt}_{\mathrm{ML}}$ electrocatalysts with nanoparticle core of different compositions by the electrochemical method as well as the compositional effect of the core materials on the activity of $\mathrm{Pt}_{\mathrm{ML}}$ electrocatalysts for electro-oxidation of ammonia. Interestingly, this study shows that the composition of the nanoparticle core had a great influence on the intrinsic activity of $\mathrm{Pt}_{\mathrm{ML}}$ electrocatalysts. 


\section{Results and Discussion}

Figure 1a-e shows the SEM images of electrodeposited $\mathrm{Ru}, \mathrm{Rh}, \mathrm{Pd}, \mathrm{Ir}$, and $\mathrm{Au}$ nanoparticles, respectively. It can be seen that all these deposited nanoparticles were randomly distributed over the surface of the glassy carbon electrode (GCE). Due to the different nature of these five metals, it is very difficult to obtain different kinds of nanoparticles with exactly the same particle size. As mentioned in the experimental part, preliminary work has tried various electrodeposition parameters including potentials and times, and finally found the optimal conditions to synthesize these five kinds of nanoparticles with a similar particle size. The particle size distribution histograms in insets of Figure 1 show that the average particle sizes for electrodeposited $\mathrm{Ru}, \mathrm{Rh}, \mathrm{Pd}$, Ir, and $\mathrm{Au}$ nanoparticles were $34.2 \pm 7.9 \mathrm{~nm}, 15.2 \pm 3.2 \mathrm{~nm}, 18.8 \pm 1.7 \mathrm{~nm}, 24.2 \pm 2.9 \mathrm{~nm}, 21.4 \pm 5.1 \mathrm{~nm}$, respectively. It was also noticed that much larger overpotential (i.e., more negative deposition potential) was required for the electrodeposition of Ru and Ir compared to other metals. Similar results have also been reported by previous studies for the electrodeposition of Ru [34] and Ir [35], due to the slow kinetics for their deposition. For example, Le Vot et al. [35] reported that the deposition of Ir on GCE required a large overpotential for the reduction of $\mathrm{Ir}^{3+}$ ions in $1.0 \mathrm{mM} \mathrm{IrCl}_{3}+0.5 \mathrm{M} \mathrm{H}_{2} \mathrm{SO}_{4}$ solution. In their work, the lowest deposition potential was $-0.6 \mathrm{~V}$ (vs. $\mathrm{Ag} / \mathrm{AgCl}$ ). The Ir deposits electrodeposited at this potential were characterized by large aggregates at several micrometers in size, indicating that the deposition process was very slow, and Ir tended to be deposited on previously formed Ir deposits than on the carbon substrate [35]. However, in the present work, Ir nanoparticles with good dispersion and small particle size of $24.2 \pm 2.9 \mathrm{~nm}$ could be obtained at a further decreasing deposition potential of $-0.7 \mathrm{~V}$ (vs. reversible hydrogen electrode (RHE)) in $5 \mathrm{mM} \mathrm{IrCl}_{3}+0.05 \mathrm{M} \mathrm{H}_{2} \mathrm{SO}_{4}$ solution (Figure 1d). Such well-dispersed Ir nanoparticles are beneficial for increasing the effective surface area.
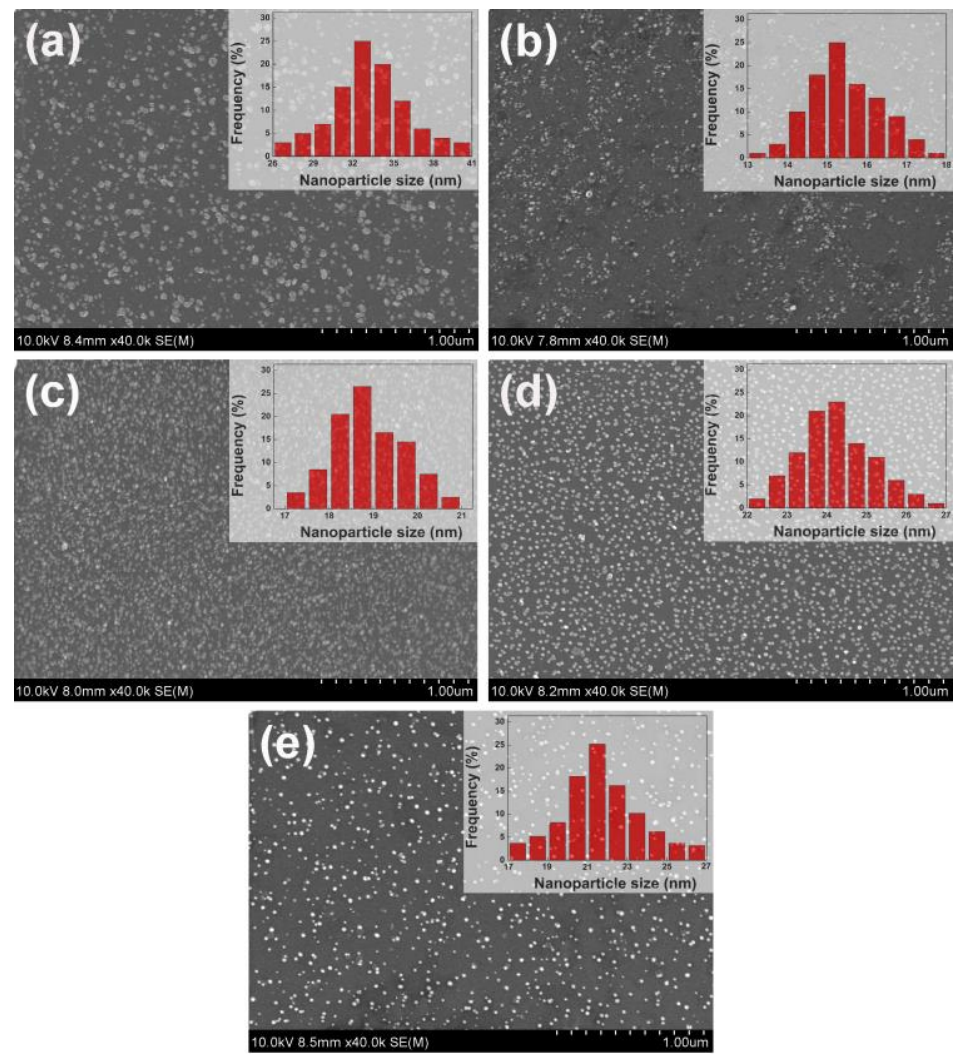

Figure 1. Scanning electron microscopy (SEM) images of (a) Ru, (b) Rh, (c) Pd, (d) Ir, and (e) Au nanoparticles electrodeposited on the GCE, respectively. Insets of SEM images show the corresponding particle size distribution histogram. 
Figure 2a-e shows the cyclic voltammetry (CV) curves of pure Ru, Rh, Pd, Ir, and Au nanoparticles electrodeposited on the GCE in $0.5 \mathrm{M} \mathrm{H}_{2} \mathrm{SO}_{4}$ solution at a scan rate of $0.05 \mathrm{~V} \mathrm{~s}^{-1}$. Rh, Ir and Pd nanoparticles showed characteristic hydrogen adsorption and desorption (0.05 to $0.2 \mathrm{~V}$ (vs. RHE)) peaks while no such hydrogen adsorption/desorption peaks could be observed for $\mathrm{Au}$ and $\mathrm{Ru}$ nanoparticles. All these CV curves exhibited very similar features compared to previously reported nanoparticles synthesized by a water-in-oil microemulsion method [36].
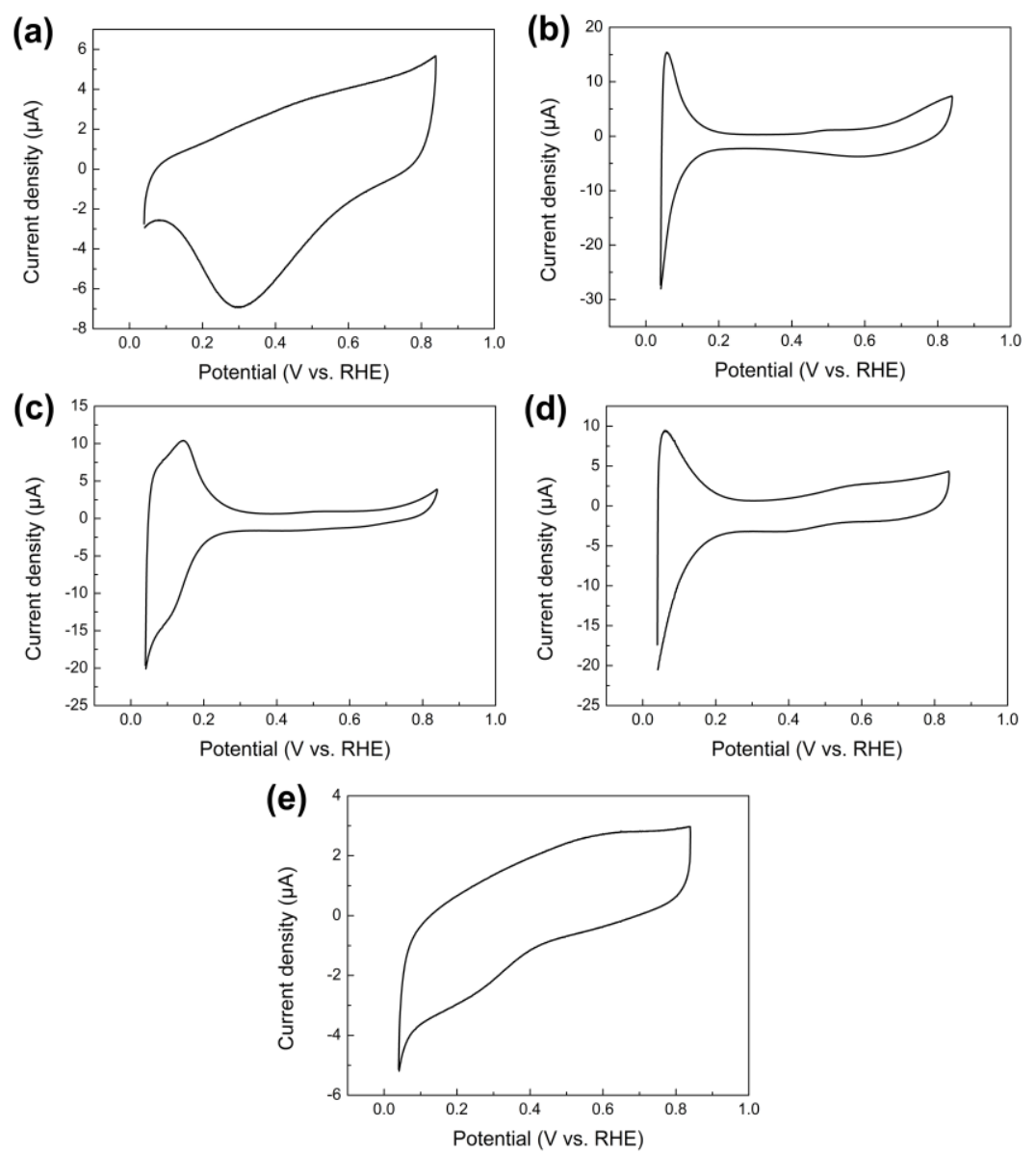

Figure 2. CVs measured on pure (a) Ru, (b) Rh, (c) Pd, (d) Ir, and (e) Au nanoparticles electrodeposited on the GCE in $0.5 \mathrm{M} \mathrm{H}_{2} \mathrm{SO}_{4}$ solution at $0.05 \mathrm{~V} \mathrm{~s}^{-1}$, respectively.

Figure 3a-e shows $\mathrm{CV}$ s measured on pure $\mathrm{Ru}, \mathrm{Rh}, \mathrm{Pd}$, Ir, and $\mathrm{Au}$ nanoparticles electrodeposited on the GCE in $0.1 \mathrm{M}$ ammonia $+1 \mathrm{M} \mathrm{KOH}$ aqueous solution at $0.05 \mathrm{~V} \mathrm{~s}^{-1}$. Only for Ir nanoparticles did the CV curve exhibited an anodic current peak at $0.59 \mathrm{~V}$ (vs. RHE) (Figure 3d). Such an oxidation current peak has been extensively reported on pure Ir and also Pt electrodes and is ascribed to the electro-oxidation of ammonia to $\mathrm{N}_{2}[12,13,37]$. Previous work performed $\mathrm{CV}$ measurements in the absence of ammonia and found that a such characteristic current peak did not appear [13,37,38]. For $4 \mathrm{~d}$ transition metals (i.e., $\mathrm{Ru}, \mathrm{Rh}$ and $\mathrm{Pd}$ ), all $\mathrm{CV}$ plots showed no anodic oxidation current peak related with the ammonia electro-oxidation from 0.4 to $0.7 \mathrm{~V}$ (vs. RHE). This is in good agreement with previous results reported by de Vooys et al. [13] and Vidal-Iglesias et al. [36]. Based on differential electrochemical mass spectroscopy (DEMS) measurements, de Vooys et al. [13] found the dehydrogenation of ammonia occurred at significantly lower potentials on $\mathrm{Ru}, \mathrm{Rh}$ and Pd than that on $\mathrm{Pt}$ and Ir, resulting in the surface poisoning by adsorbed nitrogen atoms $\left(\mathrm{N}_{\mathrm{ads}}\right)$ at much lower potentials on $\mathrm{Ru}, \mathrm{Rh}$ and $\mathrm{Pd}$. As a result, $\mathrm{Ru}, \mathrm{Rh}$ and Pd were inactive towards the ammonia electro-oxidation to $\mathrm{N}_{2}$ [13]. It was also observed that the peak height at $0.2 \mathrm{~V}$ (vs. RHE) for Rh nanoparticles (Figure 3b) is remarkably higher compared to other metals. This agrees well with previous studies reported by Cooper et al. [39], which attributed such peak to the $\mathrm{OH}^{-}$adsorption by $\mathrm{Rh}$. 

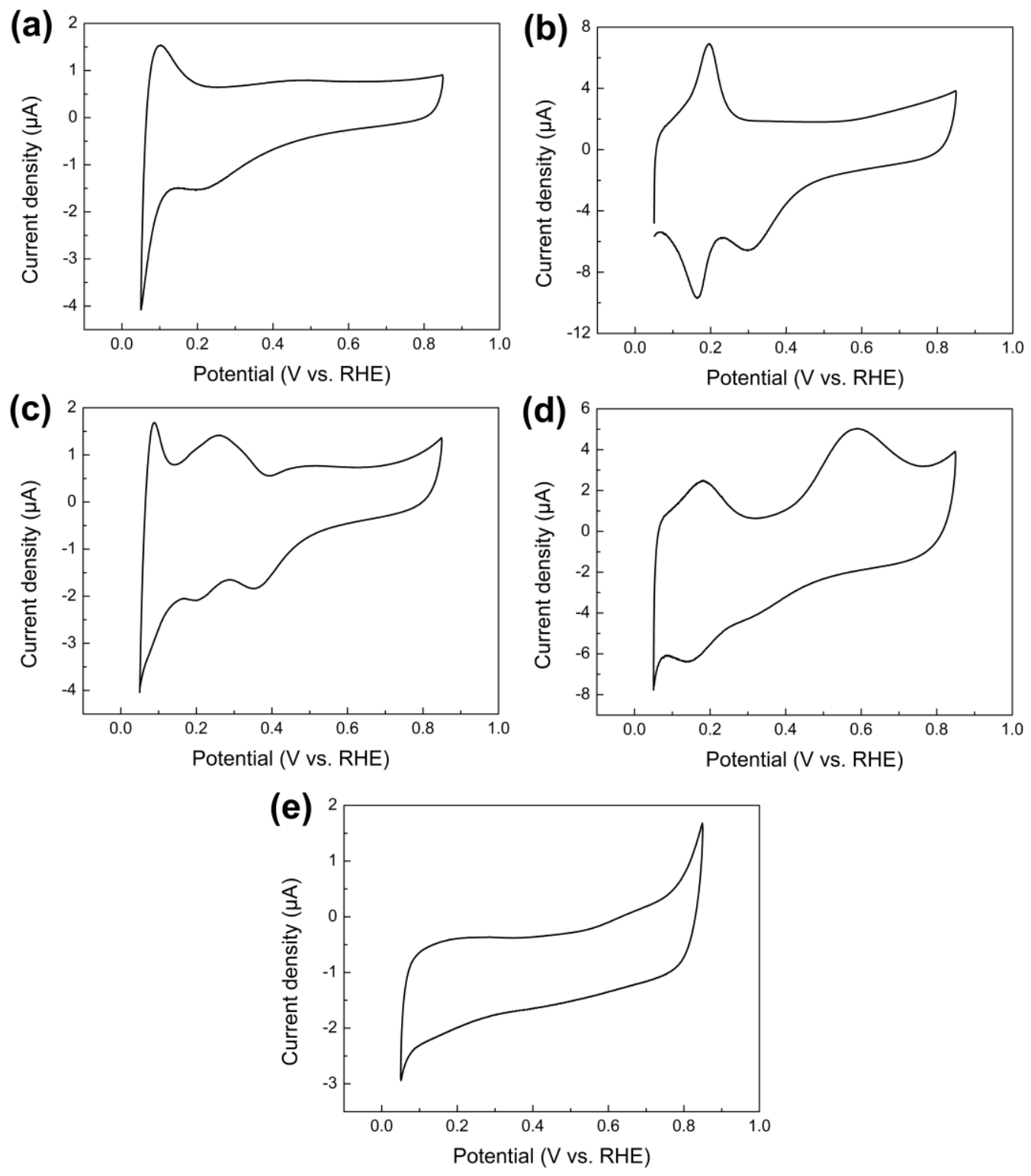

Figure 3. CVs of the ammonia electro-oxidation on pure (a) Ru, (b) Rh, (c) Pd, (d) Ir, and (e) $\mathrm{Au}$ nanoparticles electrodeposited on the GCE in aqueous solution containing $1 \mathrm{M} \mathrm{KOH}+0.1 \mathrm{M}$ ammonia at $0.05 \mathrm{~V} \mathrm{~s}^{-1}$, respectively.

Figure 4a-e shows anodic stripping voltammograms of $\mathrm{Cu}$ UPD adlayer on synthesized $\mathrm{Ru}$, $\mathrm{Rh}, \mathrm{Pd}$, Ir and Au nanoparticles on the GCE, respectively. All these curves showed typical Cu UPD stripping peaks. The amount and the corresponding surface area of the UPD $\mathrm{Cu}$ layer could be estimated from the stripping charge of the UPD $\mathrm{Cu}$, as calculated by integrating the area covered by the $\mathrm{Cu}$ stripping current peak after subtracting the background [33,40,41]. To achieve the formation of $\mathrm{Pt}_{\mathrm{ML}}$ on those metal nanoparticles, the GCE was immersed into $5 \mathrm{mM} \mathrm{K}_{2} \mathrm{PtCl}_{4}$ and $0.05 \mathrm{M} \mathrm{H}_{2} \mathrm{SO}_{4}$ solution for the galvanic replacement of the surface $\mathrm{Cu}$ monolayer by $\mathrm{Pt}$ ions. Assuming that the Faraday efficiency of the replacement reaction between the UPD Cu and Pt ions is $100 \%$, the amount and the corresponding surface area of the formed Pt can be calculated based on the amount of UPD $\mathrm{Cu}$ monolayer. The corresponding surface area of $\mathrm{Pt}$ can also be measured by the stripping charge of $\mathrm{Cu}$ UPD monolayer, assuming $480 \mu \mathrm{C} \mathrm{cm}^{-2}$ for $\mathrm{Pt}_{\mathrm{ML}}[19,42]$. The calculated data of the $\mathrm{Cu}$ stripping charge, $\mathrm{Cu}$ amount, $\mathrm{Pt}$ amount and $\mathrm{Pt}$ surface area are summarized in Table 1. 

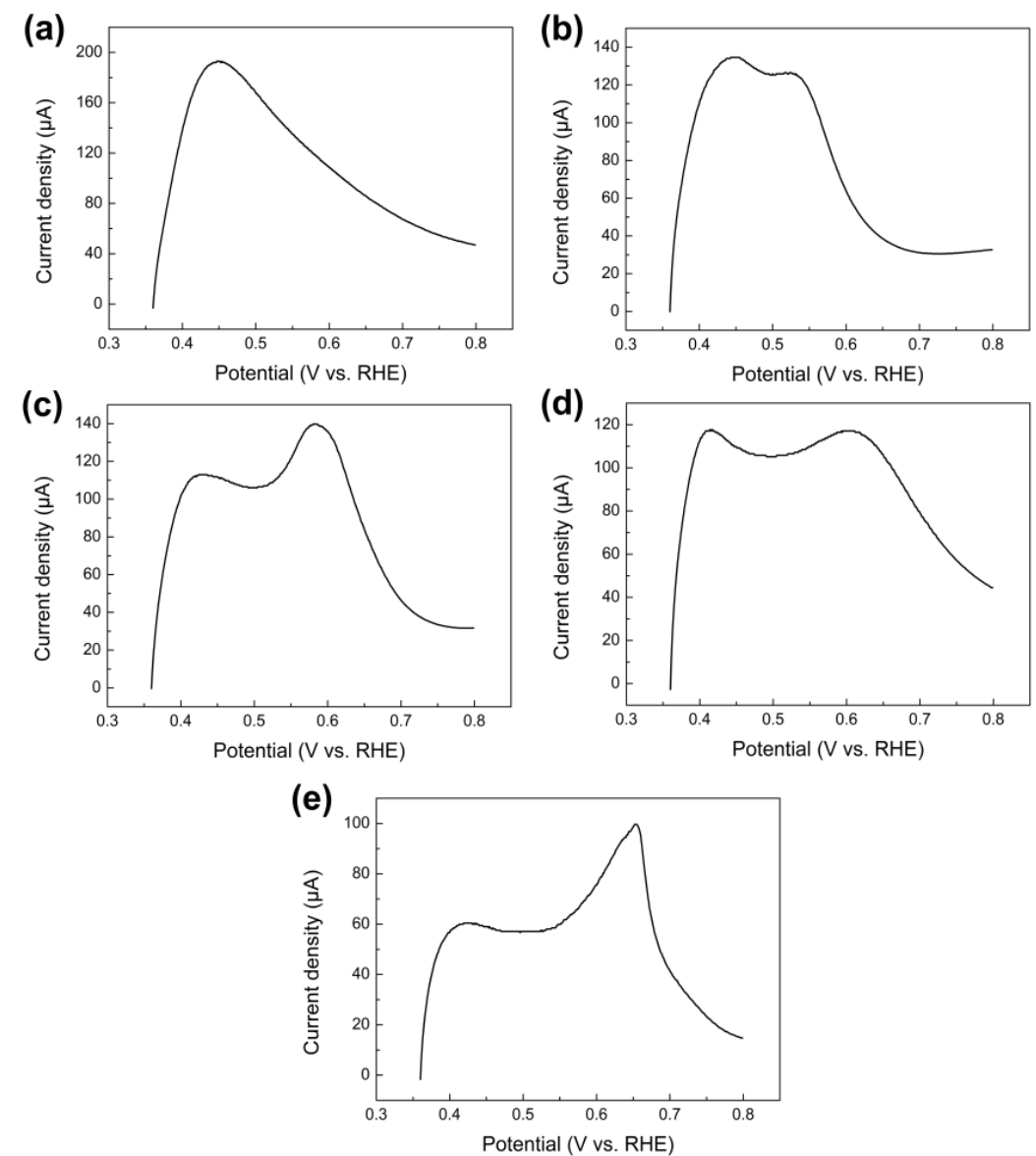

Figure 4. Anodic stripping voltammograms after Cu UPD on electrodeposited (a) Ru, (b) Rh, (c) Pd, (d) Ir and (e) Au nanoparticles on the GCE, respectively.

Table 1. Calculated values of the $\mathrm{Cu}$ stripping charge, $\mathrm{Cu}$ amount, $\mathrm{Pt}$ amount and $\mathrm{Pt}$ surface area.

\begin{tabular}{ccccc}
\hline $\begin{array}{c}\text { Composition of } \\
\text { Nanoparticle Supports }\end{array}$ & $\begin{array}{c}\text { Cu Stripping } \\
\text { Charge }(\boldsymbol{\mu C})\end{array}$ & $\begin{array}{c}\text { Cu Amount } \\
(\boldsymbol{\mu g})\end{array}$ & $\begin{array}{c}\text { Pt Amount } \\
(\boldsymbol{\mu g})\end{array}$ & $\begin{array}{c}\text { Pt Surface Area } \\
\left(\mathbf{c m}^{\mathbf{2}} \mathbf{\mu g}^{-\mathbf{1}} \mathbf{)}\right.\end{array}$ \\
\hline $\mathrm{Ru}$ & 70.45 & 0.023 & 0.071 & 0.147 \\
$\mathrm{Rh}$ & 50.48 & 0.017 & 0.051 & 0.105 \\
$\mathrm{Pd}$ & 60.98 & 0.020 & 0.062 & 0.127 \\
$\mathrm{Ir}$ & 54.68 & 0.018 & 0.055 & 0.114 \\
$\mathrm{Au}$ & 43.98 & 0.015 & 0.044 & 0.092 \\
\hline
\end{tabular}

Figure 5a-e shows the transmission electron microscopy (TEM) images of $\mathrm{Pt}_{\mathrm{ML}}$ nanoparticles with $\mathrm{Ru}, \mathrm{Rh}, \mathrm{Pd}, \mathrm{Ir}$, and Au cores, respectively. As a result of TEM sample synthesis, which is required to strip nanoparticles from GCE and then to transfer them to the $\mathrm{Cu}$ grid, it is unavoidable to result in the agglomeration of nanoparticles. Therefore, it could be seen that $\mathrm{Pt}_{\mathrm{ML}}$ nanoparticles with different composition cores were not dispersed uniformly, showing some extent of agglomeration (Figure 5) compared to freshly electrodeposited core nanoparticles (Figure 1). Nevertheless, it is clear that the overall structure of a single $\mathrm{Pt}_{\mathrm{ML}}$ nanoparticle with different composition cores consisted of the smaller, interconnected nanoparticles, suggesting a large surface area. Obviously, the $\mathrm{Pt}_{\mathrm{ML}}$ nanoparticles with different composition cores observed in SEM images (Figure 1) were composed of interconnected smaller nanoparticles. The insets of Figure 5 show the corresponding small nanoparticle size distribution histograms. It could be seen that the average nanoparticle sizes of the small $\mathrm{Pt}_{\mathrm{ML}}$ nanoparticles with $\mathrm{Ru}, \mathrm{Rh}, \mathrm{Pd}$, Ir, and Au cores were approximately $4.1 \mathrm{~nm}, 5.0 \mathrm{~nm}, 2.6 \mathrm{~nm}, 4.9 \mathrm{~nm}$ and $4.4 \mathrm{~nm}$ respectively (the insets of Figure 5), and all of which had narrow nanoparticle size distribution. 

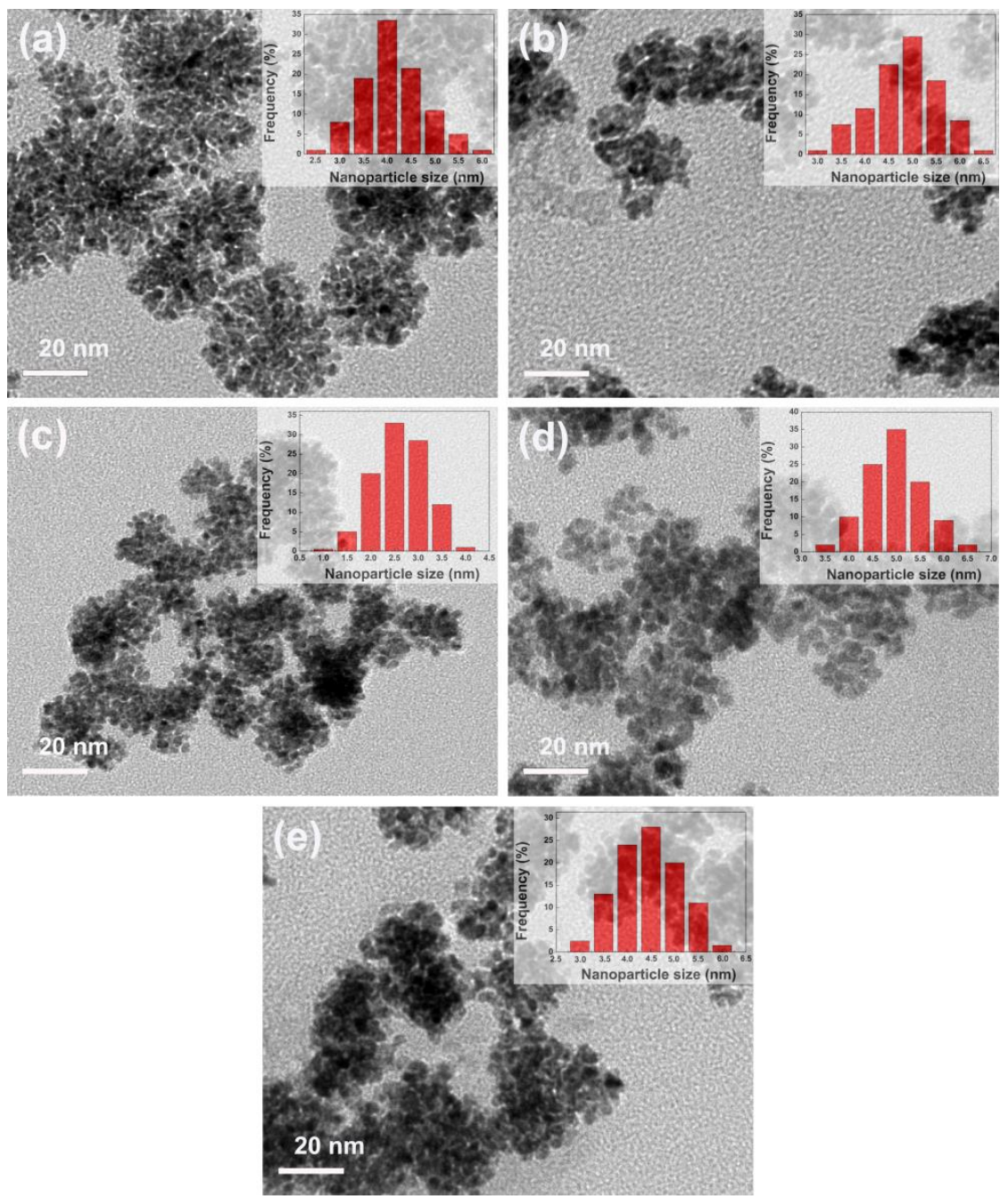

Figure 5. TEM images of $\mathrm{Pt}_{\mathrm{ML}}$ particles with (a) $\mathrm{Ru},(\mathbf{b}) \mathrm{Rh},(\mathbf{c}) \mathrm{Pd}$, (d) $\mathrm{Ir}$, and (e) $\mathrm{Au}$ cores electrodeposited on the GCE, respectively. Insets of TEM images show the corresponding particle size distribution histogram.

Figure 6a-e shows CVs measured on $\mathrm{Pt}_{\mathrm{ML}}$ nanoparticles with different core compositions in $0.5 \mathrm{M} \mathrm{H}_{2} \mathrm{SO}_{4}$ solution at a scan rate of $0.05 \mathrm{~V} \mathrm{~s}^{-1}$. Compared to Figure 2, a significant change in the electrochemical behavior could be observed after applying a $\mathrm{Pt}_{\mathrm{ML}}$ on nanoparticles. All CV profiles had typical voltammetric characteristics of $\mathrm{Pt}$ in $\mathrm{H}_{2} \mathrm{SO}_{4}$ aqueous solution, showing characteristic potential regions including the hydrogen adsorption/desorption region from 0.05 to $0.3 \mathrm{~V}$ (vs. RHE) and the double-layer region from 0.3 to $0.85 \mathrm{~V}$ (vs. RHE) [43]. It has been extensively reported that the hydrogen desorption profile on pure polycrystalline $\mathrm{Pt}$ is characterized by two well-separated anodic peaks $[5,36,44,45]$. However, $\mathrm{Pt}_{\mathrm{ML}}$ nanoparticles showed only one relatively broad anodic peak in the hydrogen desorption region. Similar results have also been widely reported by previous studies, which is attributed to the interaction between the $\mathrm{Pt}_{\mathrm{ML}}$ and the substrate [32,46-49]. The above results provide clear evidence of the formation of the $\mathrm{Pt}_{\mathrm{ML}}$ on these nanoparticles. Generally, the electrochemically active surface area of pure Pt can be estimated from the CV based on the charge related with the hydrogen desorption [50-53]. However, in the case of $\mathrm{Pt}_{\mathrm{ML}}$ nanoparticles, the hydrogen desorption profile would be affected due to the interaction between underlying core particles and the $\mathrm{Pt}_{\mathrm{ML}}$, therefore it is possibly not accurate to calculate the effective surface area of $\mathrm{Pt}$. Therefore, previous studies, including the present work, used the amount of $\mathrm{Cu}$ monolayer to estimate the $\mathrm{Pt}$ surface area assuming the complete replacement of $\mathrm{Cu}$ by $\mathrm{Pt}$ (Table 1). 

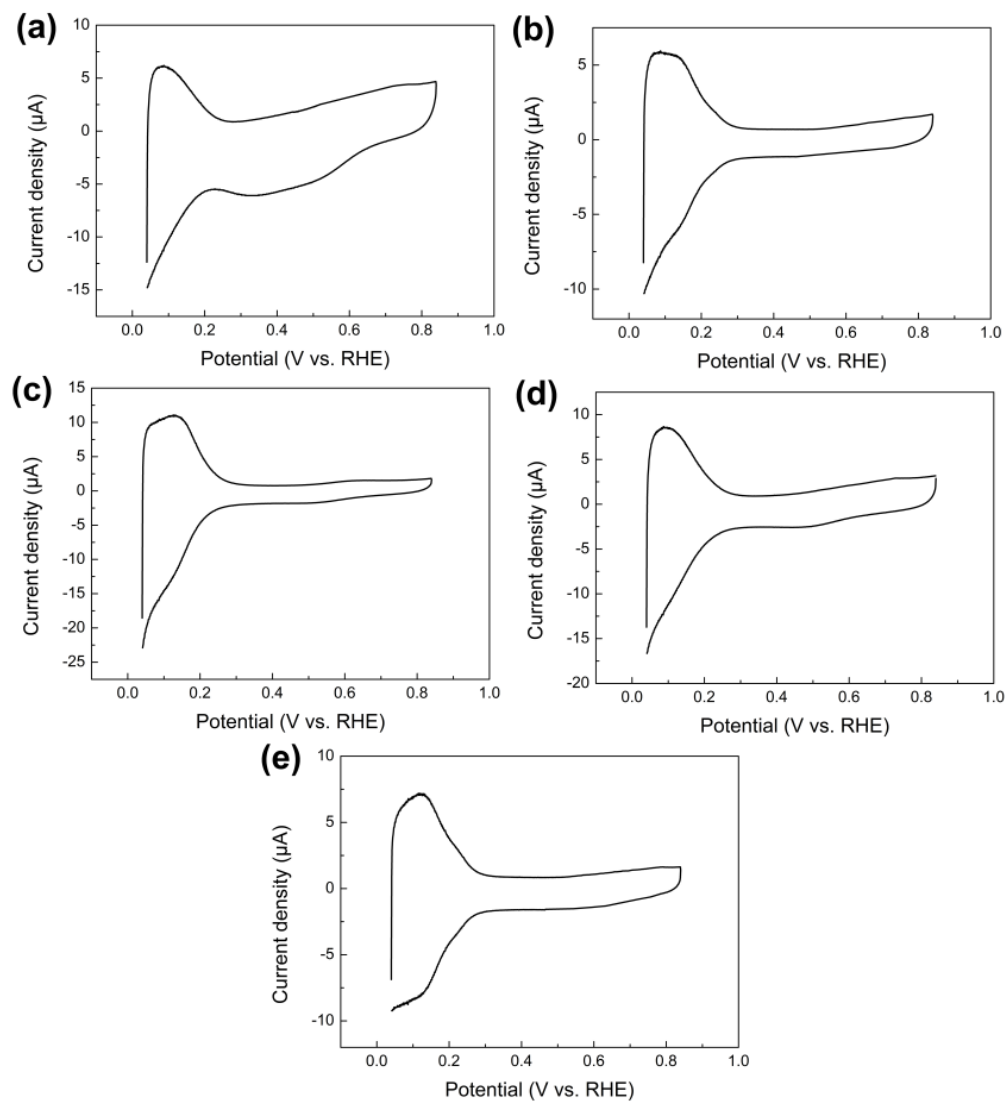

Figure 6. $\mathrm{CVs}$ measured on (a) $\mathrm{Pt}_{\mathrm{ML}} / \mathrm{Ru}$ nanoparticles, (b) $\mathrm{Pt}_{\mathrm{ML}} / \mathrm{Rh}$ nanoparticles, (c) $\mathrm{Pt}_{\mathrm{ML}} / \mathrm{Pd}$ nanoparticles, (d) $\mathrm{Pt}_{\mathrm{ML}} / \mathrm{Ir}$ nanoparticles, and (e) $\mathrm{Pt}_{\mathrm{ML}} / \mathrm{Au}$ nanoparticles on the GCE in $0.5 \mathrm{M} \mathrm{H}_{2} \mathrm{SO}_{4}$ solution, respectively.

To investigate the electrocatalytic activity for the electro-oxidation of ammonia, Figure 7a shows the CVs measured on five different $\mathrm{Pt}_{\mathrm{ML}}$ covered nanoparticles in $0.1 \mathrm{M}$ ammonia $+1 \mathrm{M} \mathrm{KOH}$. In order to reveal the SA, the current was normalized by the effective electrochemical surface area. Compared to observed CVs on bare nanoparticles (Figure 3), applying a $\mathrm{Pt}_{\mathrm{ML}}$ on these nanoparticles resulted in an obvious change of $\mathrm{CV}$ curves. All five $\mathrm{CV}$ curves showed a current peak around $0.7 \mathrm{~V}$ (vs. RHE) on the positive sweep, which is a typical feature of ammonia electro-oxidation on $\mathrm{Pt}$ as previously discussed. This again confirms the successful deposition of $\mathrm{Pt}$ on various nanoparticles by the replacement of UPD Cu. It is worth noticing that the SA of $\mathrm{Pt}_{\mathrm{ML}}$ covered nanoparticles strongly depends on the composition of core nanoparticles, which can be clearly seen in Figure $7 \mathrm{~b}$. The SA for electro-oxidation of ammonia decreases in the following order: $\mathrm{Pt}_{\mathrm{ML}} / \mathrm{Au}$ nanoparticles $>\mathrm{Pt}_{\mathrm{ML}} / \mathrm{Ir}$ nanoparticles $\approx \mathrm{Pt}_{\mathrm{ML}} / \mathrm{Rh}$ nanoparticles $>\mathrm{Pt}_{\mathrm{ML}} / \mathrm{Ru}$ Nanoparticles $\approx \mathrm{Pt}_{\mathrm{ML}} / \mathrm{Pd}$ nanoparticles. $\mathrm{Pt} \mathrm{ML}_{\mathrm{ML}}$ supported on Au nanoparticles showed the highest SA, which was about 8.3 times higher than that on $\mathrm{Ru}$ and Pd nanoparticles. In addition, compared to other Pt-based catalysts reported in previous work, the obtained $\mathrm{Pt}_{\mathrm{ML}} / \mathrm{Au}$ nanoparticles exhibited relatively high SA for electrooxidation ammonia and $\mathrm{Pt}$ surface area among the various catalysts (Table 2). As a typical representative, as-prepared $\mathrm{Pt}_{\mathrm{ML}} / \mathrm{Au}$ nanoparticles are provided in Figure 7c since it exhibited highest SA among the obtained catalysts. The high-resolution transmission electron microscopy (HRTEM) image showed the clear lattice fringes indicating a high crystallinity of the $\mathrm{Pt}_{\mathrm{ML}} / \mathrm{Au}$ nanoparticles, and it also revealed that the $\mathrm{Pt}_{\mathrm{ML}} / \mathrm{Au}$ nanoparticles were composed of multiple crystalline domains, suggesting a polycrystalline structure. The widely accepted mechanism of ammonia electro-oxidation on $\mathrm{Pt}$ was proposed by Gerischer and Mauerer [54], involving dehydrogenation of $\mathrm{NH}_{3, \text { ads }}$ to $\mathrm{NH}_{x, \text { ads }}(\mathrm{x}=1$ or 2) intermediates and $\mathrm{N}_{\mathrm{ads}}$. The partially dehydrogenated $\mathrm{NH}_{2, \text { ads }}$ species are key precursors to promote the formation of $\mathrm{N}_{2} \mathrm{H}_{4}$ that is then dehydrogenated quickly to $\mathrm{N}_{2}$ [54]. This mechanism has been later confirmed by 
experimental methods [55,56] and density functional theory calculations [57], supporting that $\mathrm{NH}_{2}$ species are active intermediates, and therefore a Pt surface with a higher binding energy of $\mathrm{NH}_{2}$ intermediates has higher activity for ammonia electro-oxidation. Previous studies found that due to the lattice mismatch between the $\mathrm{Pt}_{\mathrm{ML}}$ and the substrate, different level of tensile or compressive strain is exerted on the $\mathrm{Pt}_{\mathrm{ML}}$ depending on the substrate material [19]. For example, Au exerts a tensile strain on $\mathrm{Pt}_{\mathrm{ML}}$ (over $4 \%$ ) while other metals such as $\mathrm{Pd}$, $\mathrm{Ru}$ and $\mathrm{Rh}$ exert on it a comprehensive strain (about $-2 \sim-4 \%$ ) [19]. This affects the binding abilities of the $\mathrm{Pt}_{\mathrm{ML}}$ and thus changes the surface activity. In consistence with theoretical calculations [58,59], Li et al. [19] demonstrated that the tensile surface strain in the $\mathrm{Pt}_{\mathrm{ML}}$ (e.g., $\mathrm{Pt}_{\mathrm{ML}}$ supported on $\mathrm{Au}$ ) tends to upshift the weighted center of the d-band $\left(\varepsilon_{\mathrm{d}}\right)$ in energy and thus increases the binding of $\mathrm{CO}$ and $\mathrm{OH}$. This contributes to a significant enhancement in the activity of the $\mathrm{Pt}_{\mathrm{ML}}$ on Au towards electrocatalytic oxidation of methanol and ethanol [19]. On the contrary, $\mathrm{Pt}_{\mathrm{ML}}$ on other substrates (i.e., $\mathrm{Ru}, \mathrm{Rh}$, $\mathrm{Ir}$ and $\mathrm{Pd}$ ) is under compressive strain, resulting in decreased activity for the electro-oxidation of methanol and ethanol [19]. It is interesting to note that the substrate-induced surface strain effect on activity was also been found in the present work. For example, the $\mathrm{Pt}_{\mathrm{ML}}$ supported on electrodeposited Au nanoparticles showed significantly higher SA compared to that supported on electrodeposited Pd and Ru nanoparticles. Similarly, the tensile surface strain in the $\mathrm{Pt}_{\mathrm{ML}}$ induced by the substrate $\mathrm{Au}$ is expected to increase the binding of the $\mathrm{Pt}_{\mathrm{ML}}$ for active intermediates such as $\mathrm{NH}_{2}$ to activate ammonia electro-oxidation and thus improves the SA. On the contrary, $\mathrm{Pd}$ and $\mathrm{Ru}$ nanoparticles exert a compressive strain on the $\mathrm{Pt}_{\mathrm{ML}}$ [19] and therefore they have an opposite effect compared to $\mathrm{Pt}_{\mathrm{ML}}$ on $\mathrm{Au}$, exhibiting low specific activities among all investigated $\mathrm{Pt}_{\mathrm{ML}}$ nanoparticles. However, it was noticed that $\mathrm{Pt}_{\mathrm{ML}}$ on electrodeposited $\mathrm{Rh}$ and Ir nanoparticles had remarkably higher activity than those on $\mathrm{Pd}$ and $\mathrm{Ru}$ nanoparticles despite of the compressive strain exerted by $\mathrm{Rh}$ or Ir on Pt, which is different with that reported by previous studies [19]. This was due to the positive synergistic effect between Pt and Rh or Ir. Cooper et al. [39] pointed out that the presence of Rh along with $\mathrm{Pt}$ will increase active sites on the Pt surface for ammonia electro-oxidation. The synergic effect of Ir to Pt has also been reported by previous studies, which was attributed to the ability of Ir to dehydrogenate ammonia molecules at lower potentials $[36,60,61]$. Our results agree well with these studies $[36,39,60]$.
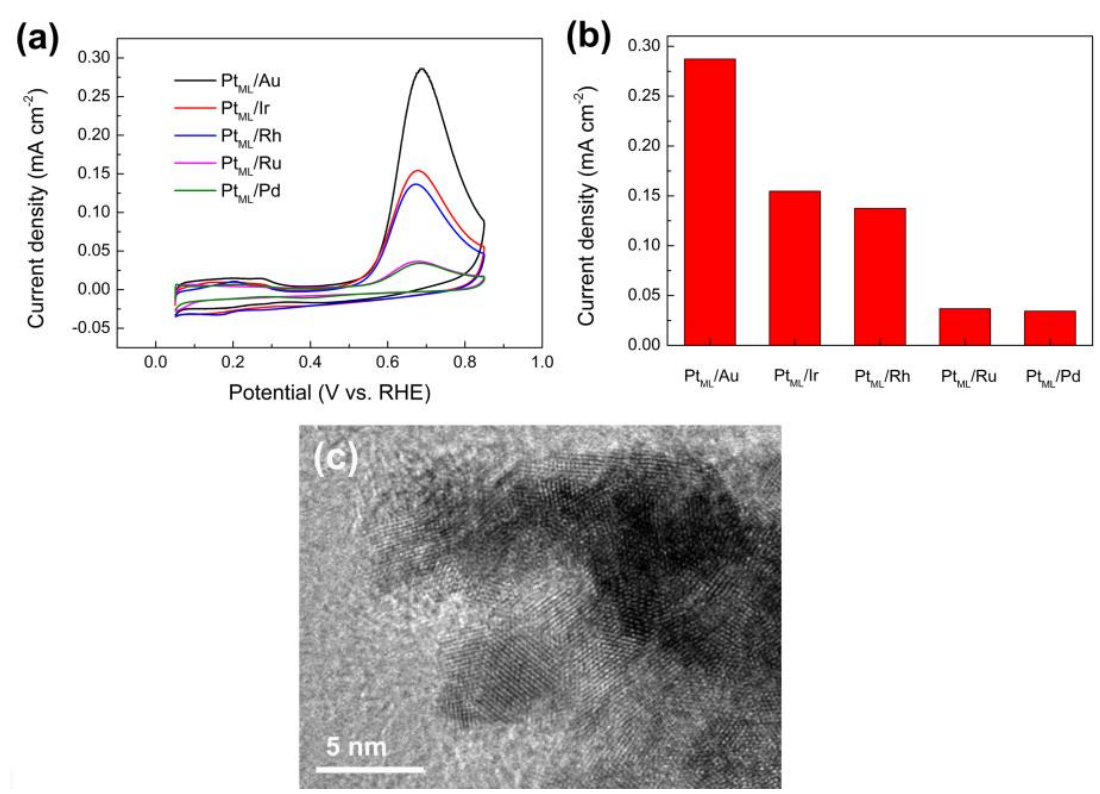

Figure 7. (a) CVs of the ammonia electro-oxidation on $\mathrm{Pt}_{\mathrm{ML}}$ supported on $\mathrm{Ru}$ nanoparticles, $\mathrm{Rh}$ nanoparticles, Pd nanoparticles, Ir nanoparticles, and Au nanoparticles on the GCE in aqueous solution containing $1 \mathrm{M} \mathrm{KOH}+0.1 \mathrm{M}$ ammonia at $0.05 \mathrm{~V} \mathrm{~s}^{-1}$, respectively. (b) Comparison of the SA of $\mathrm{Pt}_{\mathrm{ML}}$ supported on Ru nanoparticles, Rh nanoparticles, Pd nanoparticles, Ir nanoparticles, and Au nanoparticles on the GCE. (c) HRTEM image of as-prepared $\mathrm{Pt}_{\mathrm{ML}} / \mathrm{Au}$ nanoparticles. 
Table 2. Comparison of SA for ammonia electro-oxidation and Pt surface area of as-prepared electrocatalysts with previous work.

\begin{tabular}{|c|c|c|c|c|}
\hline Electrocatalyst Type & Test Protocol [a] & $\begin{array}{l}\text { Pt Surface Area }{ }^{[b]} \\
\left(\mathrm{cm}^{2} \mu \mathrm{g}^{-1}\right)\end{array}$ & $\mathrm{SA}^{[\mathrm{c}]}\left[\mathrm{mA} \mathrm{cm}^{-2}\right]$ & Reference \\
\hline $\mathrm{Pt}_{\mathrm{ML}} / \mathrm{Au}$ nanoparticles & $\begin{array}{c}0.1 \mathrm{M} \mathrm{NH}_{3} \text { and } 1 \mathrm{M} \mathrm{KOH} \\
\text { aqueous solution, scan rate } 10 \\
\mathrm{mV} \mathrm{s}^{-1}\end{array}$ & 0.092 & 0.29 & this work \\
\hline $\mathrm{Pt}_{0.8} \mathrm{Ru}_{0.2}$ alloy & $\begin{array}{c}1 \mathrm{M} \mathrm{NH}_{3} \text { and } 1 \mathrm{M} \mathrm{KOH} \\
\text { aqueous solution, scan rate } 10 \\
\qquad \mathrm{mV} \mathrm{s}^{-1}\end{array}$ & - & 0.21 & [62] \\
\hline $\mathrm{Pt}_{0.8} \mathrm{Ni}_{0.2}$ alloy & $\begin{array}{c}1 \mathrm{M} \mathrm{NH}_{3} \text { and } 1 \mathrm{M} \mathrm{KOH} \\
\text { aqueous solution, scan rate } 10 \\
\mathrm{mV} \mathrm{s}^{-1}\end{array}$ & - & 0.12 & [62] \\
\hline Polycrystalline Pt & $\begin{array}{c}1 \mathrm{mM} \mathrm{NH}_{3} \text { and } 0.1 \mathrm{M} \mathrm{NaOH} \\
\text { aqueous solution, scan rate } 10 \\
\mathrm{mV} \mathrm{s}^{-1}\end{array}$ & - & 0.12 & [63] \\
\hline $\mathrm{Pt}_{80} \mathrm{Ru}_{20}$ nanoparticles & $\begin{array}{c}0.1 \mathrm{M} \mathrm{NH}_{3} \text { and } 0.2 \mathrm{M} \mathrm{NaOH} \\
\text { aqueous solution, scan rate } 10 \\
\mathrm{mV} \mathrm{s}^{-1}\end{array}$ & - & 0.05 & [36] \\
\hline $\mathrm{Pt}_{75} \mathrm{Rh}_{25}$ nanoparticles & $\begin{array}{c}0.1 \mathrm{M} \mathrm{NH}_{3} \text { and } 0.2 \mathrm{M} \mathrm{NaOH} \\
\text { aqueous solution, scan rate } 10 \\
\mathrm{mV} \mathrm{s}^{-1}\end{array}$ & - & 0.15 & [36] \\
\hline $\mathrm{Pt}_{80} \mathrm{Pd}_{20}$ nanoparticles & $\begin{array}{c}0.1 \mathrm{M} \mathrm{NH}_{3} \text { and } 0.2 \mathrm{M} \mathrm{NaOH} \\
\text { aqueous solution, scan rate } 10 \\
\mathrm{mV} \mathrm{s}^{-1}\end{array}$ & - & 0.11 & [36] \\
\hline $\begin{array}{l}\text { Polycrystalline Pt } \\
\text { electrode }\end{array}$ & $\begin{array}{c}1 \mathrm{mM} \mathrm{NH}_{3} \text { and } 0.1 \mathrm{M} \mathrm{NaOH}^{-1} \\
\text { scan rate } 50 \mathrm{mV} \mathrm{s}^{-1}\end{array}$ & - & 0.25 & [64] \\
\hline $\begin{array}{l}\text { Pt thin films with } \\
\text { preferential }(100) \\
\text { orientation }\end{array}$ & $\begin{array}{c}0.1 \mathrm{M} \mathrm{NH}_{3} \text { and } 0.2 \mathrm{M} \mathrm{NaOH} \\
\text { aqueous solution, scan rate } 1 \\
\mathrm{mV} \mathrm{s}^{-1}\end{array}$ & - & 0.212 & [65] \\
\hline Flower-like Pt particles & - & 0.031 & - & [66] \\
\hline $\begin{array}{l}\text { Flower-like Pt particles on } \\
\text { single-walled carbon } \\
\text { nanotubes }\end{array}$ & - & 0.067 & - & [67] \\
\hline $\begin{array}{c}\text { Pt nanoparticles on GC } \\
\text { electrode electrodeposited } \\
\text { for } 2 \text { min }\end{array}$ & - & 0.017 & - & [68] \\
\hline $\begin{array}{l}\text { Pt nanoparticles on GC } \\
\text { electrode electrodeposited } \\
\text { for } 15 \mathrm{~min}\end{array}$ & - & 0.012 & - & [68] \\
\hline
\end{tabular}

\section{Experimental Section}

\subsection{Reagents}

$\mathrm{RuCl}_{3}, \mathrm{RhCl}_{3}, \mathrm{PdCl}_{2}, \mathrm{IrCl}_{3}, \mathrm{HAuCl}_{4} \cdot 3 \mathrm{H}_{2} \mathrm{O}, \mathrm{K}_{2} \mathrm{PtCl}_{4}, \mathrm{CuSO}_{4}, \mathrm{H}_{2} \mathrm{SO}_{4}$, and $\left(\mathrm{NH}_{4}\right)_{2} \mathrm{SO}_{4}$ were obtained from Beijing Chemicals (Beijing, China). All reagents employed were of analytical grade and used directly without further purification. All the aqueous solutions used in this work were prepared with ultrapure water (Milli-Q Millipore, > $18.2 \mathrm{M} \Omega \mathrm{cm}$ ).

\subsection{Electrode Synthesis and Characterization}

All electrochemical syntheses and characterizations were performed on a three-electrode setup. A glassy carbon electrode (GCE, $5 \mathrm{~mm}$ in diameter) served as the working electrode, a Pt plate $\left(1 \times 1 \mathrm{~cm}^{2}\right)$ electrode and a mercury sulfate electrode (MSE) served as counter and reference electrodes respectively. For the convenience of comparison, the potential measured by MSE was referred to reversible hydrogen electrode (vs. RHE). Prior to the electrodeposition, the GCE was first polished and then ultrasonically cleaned in ultrapure water for $3 \mathrm{~min}$. Through controlling the deposition potential under potentiostatic conditions, nanoparticles with different compositions were synthesized on the surface of GCE. Some preliminary experiments had been carried out to find out the optimal 
electrodeposition potentials and times, and the following conditions were employed to synthesize nanoparticles. Ru nanoparticles were synthesized on the GCE at $-0.8 \mathrm{~V}$ (vs. RHE) for $8 \mathrm{~s}$ in $5 \mathrm{mM}$ $\mathrm{RuCl}_{3}+0.05 \mathrm{M} \mathrm{H}_{2} \mathrm{SO}_{4}$ solution. Rh nanoparticles were synthesized on the GCE at $-0.05 \mathrm{~V}$ (vs. RHE) for $0.2 \mathrm{~s}$ in $5 \mathrm{mM} \mathrm{RhCl}_{3}+0.05 \mathrm{M} \mathrm{H}_{2} \mathrm{SO}_{4}$ solution. Pd nanoparticles were synthesized on the GCE at $0 \mathrm{~V}$ (vs. RHE) for $0.2 \mathrm{~s}$ in $5 \mathrm{mM} \mathrm{PdCl} \mathrm{m}_{2}+0.05 \mathrm{M} \mathrm{H}_{2} \mathrm{SO}_{4}$ solution. Ir nanoparticles were synthesized on the GCE at $-0.7 \mathrm{~V}$ (vs. RHE) for $800 \mathrm{~s}$ in $5 \mathrm{mM} \mathrm{IrCl}_{3}+0.05 \mathrm{M} \mathrm{H}_{2} \mathrm{SO}_{4}$ solution. Au nanoparticles were synthesized on the GCE at $0 \mathrm{~V}$ (vs. RHE) for $0.2 \mathrm{~s}$ in $5 \mathrm{mM} \mathrm{HAuCl}_{4}+0.05 \mathrm{M} \mathrm{H}_{2} \mathrm{SO}_{4}$ solution. The synthesis of $\mathrm{Pt}_{\mathrm{ML}}$ on electrodeposited nanoparticles was achieved by a well-established method, as described as follows. After the synthesis of core nanoparticles on the GCE, the modified GCE, rinsed thoroughly with ultrapure water, was transferred into $0.05 \mathrm{M} \mathrm{H}_{2} \mathrm{SO}_{4}+0.05 \mathrm{M} \mathrm{CuSO}_{4}$ aqueous solution for the subsequent $\mathrm{Cu}$ UPD. The modified GCE was initially kept at $0.8 \mathrm{~V}$ (vs. RHE) for $20 \mathrm{~s}$ to make sure there is no $\mathrm{Cu}$ on the surface $[18,33]$. The electrode potential was subsequently swept at $0.4 \mathrm{~V} \mathrm{~s}^{-1}$ to the $\mathrm{Cu}$ UPD potential of $0.36 \mathrm{~V}$ (vs. RHE) and held at this potential for $60 \mathrm{~s}[18,33]$. When the Cu UPD was finished, the corresponding GCE, rinsed thoroughly with ultrapure water, was immediately transferred into solution containing $5 \mathrm{mM} \mathrm{K}_{2} \mathrm{PtCl}_{4}$ and $0.05 \mathrm{M} \mathrm{H}_{2} \mathrm{SO}_{4}$ under the protection of high-purity $\mathrm{Ar}(99.999 \%)$ atmosphere to achieve the replacement of $\mathrm{Cu}$ with $\mathrm{Pt}^{2+}$ ions for $20 \mathrm{~min}$. After the replacement reaction, the $\mathrm{Pt}_{\mathrm{ML}}$ covered nanoparticles on the GCE were rinsed thoroughly with ultrapure water and dried in a nitrogen stream. The amount of the deposited $\mathrm{Cu}$ monolayer by UPD could be measured by the anodic stripping technique. For anodic stripping tests, the electrode potential was kept at $0.36 \mathrm{~V}$ (vs. RHE) for $60 \mathrm{~s}$ to complete the Cu UPD, and then swept back to $0.8 \mathrm{~V}$ (vs. RHE) at $0.4 \mathrm{~V} \mathrm{~s}^{-1}$ to strip off the Cu layer [33].

The particle size and dispersion degree of the $\mathrm{Pt}_{\mathrm{ML}}$ decorated nanoparticles were determined by scanning electron microscopy (SEM, S-4800, Hitachi, Tokyo, Japan) and transmission scanning electron microscopy (TEM, JEM-2100F, JEOL, Tokyo, Japan). For the TEM measurements, the electrodeposited nanoparticles were gently scraped and dispersed in ethanol on surface of GCE, and then the nanoparticle dispersions were transferred onto a $\mathrm{Cu}$ grid, which was directly conducted on surface of GCE.

\subsection{Electrochemical Tests}

Electrochemical tests were also carried out on the electrochemical workstation (IviumStat, Eindhoven, Netherland). Electrodeposited pure nanoparticles, or $\mathrm{Pt}_{\mathrm{ML}}$ covered nanoparticles, on the GCE served as the working electrode. A Pt plate $\left(1 \times 1 \mathrm{~cm}^{2}\right)$ served as the counter electrode. A CV technique was used to investigate the electrochemical performance of nanoparticles with different compositions before and after the coverage of the $\mathrm{Pt}_{\mathrm{ML}}$. For the CVs tested in $0.5 \mathrm{M}$ $\mathrm{H}_{2} \mathrm{SO}_{4}$ aqueous solution, an MSE was used as the reference electrode with a scan rate of $0.05 \mathrm{~V}$ $\mathrm{s}^{-1}$. The electro-oxidation of ammonia was conducted in aqueous solution containing $1 \mathrm{M} \mathrm{KOH}+0.1$ $\mathrm{M}$ ammonia by $\mathrm{CV}$ at $0.01 \mathrm{~V} \mathrm{~s}^{-1}$, and a $\mathrm{Hg} / \mathrm{HgO}$ (filled with $1 \mathrm{M} \mathrm{KOH}$ ) served as the reference electrode in this case. All the electrochemical measurements were performed in testing solutions saturated with argon gas (99.999\%). All the measured potentials by the reference electrode were referred to as the RHE for the convenience of comparison. All experiments were carried out at controlled temperature of $25 \pm 1{ }^{\circ} \mathrm{C}$.

\section{Conclusions}

The effect of the composition of nanoparticle supports on the electrocatalytic activity of $\mathrm{Pt}_{\mathrm{ML}}$ electrocatalysts for ammonia oxidation was investigated. A clean electrochemical approach free of binders, surfactants, capping agents and reductants was proposed to synthesis nanoparticle supports with various compositions including $\mathrm{Ru}, \mathrm{Rh}, \mathrm{Pd}$, Ir and $\mathrm{Au}$. $\mathrm{Pt}_{\mathrm{ML}}$ supported on different nanoparticles were obtained by the $\mathrm{Cu}$ UPD and subsequent replacement of Pt ions. The SA of the $\mathrm{Pt}_{\mathrm{ML}}$ electrocatalysts was significantly dependent on the composition of nanoparticle supports, which decreased in the following order: $\mathrm{Pt}_{\mathrm{ML}} / \mathrm{Au}$ nanoparticles $>\mathrm{Pt}_{\mathrm{ML}} / \mathrm{Ir}$ nanoparticles $\approx \mathrm{Pt}_{\mathrm{ML}} / \mathrm{Rh}$ 
nanoparticles $>\mathrm{Pt}_{\mathrm{ML}} / \mathrm{Ru}$ Nanoparticles $\approx \mathrm{Pt}_{\mathrm{ML}} / \mathrm{Pd}$ nanoparticles. The $\mathrm{SA}$ of the $\mathrm{Pt}_{\mathrm{ML}}$ supported on Au nanoparticles was about 8.3 times higher than that of the $\mathrm{Pt}_{\mathrm{ML}}$ supported on $\mathrm{Ru}$ Nanoparticles and Pd Nanoparticles. This trend was generally related to the change of the surface strain in the $\mathrm{Pt}_{\mathrm{ML}}$ exerted by the nanoparticle support. As the surface strain in the $\mathrm{Pt}_{\mathrm{ML}}$ exerted by the nanoparticle support changed from a tensile strain to a compressive strain, the SA of $\mathrm{Pt}_{\mathrm{ML}}$ electrocatalysts decreased. Therefore, the highest SA was observed for the $\mathrm{Pt}_{\mathrm{ML}}$ supported on the Au nanoparticles, where the $\mathrm{Pt}_{\mathrm{ML}}$ was under a tensile strain. On the contrary, for $\mathrm{Ru}, \mathrm{Rh}$ and $\mathrm{Pd}$ nanoparticle supports that exerted on the $\mathrm{Pt}_{\mathrm{ML}}$ a tensile strain had much lower specific activities.

Author Contributions: J.L. and B.L. contributed equally to this work, that is, they performed the synthesis, electrochemical characterizations of the catalysts and wrote the draft. X.C. and J.Z. carried out structural characterizations with SEM and TEM. Y.W. and Y.D. contributed to the data analysis. W.H. supervised the project. C.Z. supervised the project, designed the experiments and revised manuscript.

Funding: This work was supported by the National Science Foundation for Excellent Young Scholar (No. 51722403), the National Natural Science Foundation of China (Nos. 51771134, 51571151, 51801134 and 51701139), the National Natural Science Foundation of China and Guangdong Province (No. U1601216), the Tianjin Natural Science Foundation (Nos. 16JCYBJC17600 and 18JCJQJC46500), and the National Youth Talent Support Program.

Conflicts of Interest: The authors declare no conflict of interest.

\section{References}

1. Li, G.; Kanezashi, M.; Tsuru, T. Catalytic Ammonia Decomposition over High-Performance Ru/Graphene Nanocomposites for Efficient $\mathrm{CO}_{\mathrm{x}}$-Free Hydrogen Production. Catalysts 2017, 7, 23. [CrossRef]

2. Liu, J.; Chen, B.; Kou, Y.; Liu, Z.; Chen, X.; Li, Y.B.; Deng, Y.D.; Han, X.P.; Hu, W.B.; Zhong, C. Pt-Decorated highly porous flower-like Ni particles with high mass activity for ammonia electro-oxidation. J. Mater. Chem. A 2016, 4, 11060-11068. [CrossRef]

3. Liao, C.H.; Huang, C.W.; Wu, J.C.S. Hydrogen Production from Semiconductor-based Photocatalysis via Water Splitting. Catalysts 2012, 2, 490-516. [CrossRef]

4. Liu, J.; Liu, B.; Ni, Z.Y.; Deng, Y.D.; Zhong, C.; Hu, W.B. Improved Catalytic Performance of Pt/TiO 2 Nanotubes Electrode for Ammonia Oxidation under UV-light Illumination. Electrochim. Acta 2014, 150, 146-150. [CrossRef]

5. Liu, J.; Zhong, C.; Du, X.T.; Wu, Y.T.; Xu, P.Z.; Liu, J.B.; Hu, W.B. Pulsed Electrodeposition of Pt Particles on Indium Tin Oxide Substrates and Their Electrocatalytic Properties for Methanol Oxidation. Electrochim. Acta 2013, 100, 164-170. [CrossRef]

6. Sala, R.; Dzida, J.; Krasowski, J. Ammonia concentration distribution measurements on selective catalytic reduction catalysts. Catalysts 2018, 8, 231. [CrossRef]

7. Strickland, G. Hydrogen Derived from Ammonia: Small-scale Costs. Int. J. Hydrogen Energy 1984, 9, 759-766. [CrossRef]

8. Jiang, D.; Zhang, S.; Zeng, Y.; Wang, P.; Zhong, Q. Active site of $\mathrm{O}_{2}$ and its improvement mechanism over Ce-Ti catalyst for $\mathrm{NH}_{3}$-SCR reaction. Catalysts 2018, 8, 336. [CrossRef]

9. Yao, K.; Cheng, Y.F. Fabrication by electrolytic deposition of Pt-Ni electrocatalyst for oxidation of ammonia in alkaline solution. Int. J. Hydrogen Energy 2008, 33, 6681-6686. [CrossRef]

10. Wang, R.; Wu, X.; Zou, C.; Li, X.; Du, Y. NO $\mathrm{NO}_{\mathrm{x}}$ removal by selective catalytic reduction with ammonia over a hydrotalcite-derived NiFe mixed oxide. Catalysts 2018, 8, 384. [CrossRef]

11. Boggs, B.K.; Botte, G.G. On-board Hydrogen Storage and Production: An Application of Ammonia Electrolysis. J. Power Sources 2009, 192, 573-581. [CrossRef]

12. Galipaud, J.; Roy, C.; Martin, M.H.; Garbarino, S.; Roué, L.; Guay, D. Electrooxidation of Ammonia at Tuned (100)Pt Surfaces by Using Epitaxial Thin Films. ChemElectroChem 2015, 2, 1187-1198. [CrossRef]

13. De Vooys, A.C.A.; Koper, M.T.M.; van Santen, R.A.; van Veen, J.A.R. The Role of Adsorbates in the Electrochemical Oxidation of Ammonia on Noble and Transition Metal Electrodes. J. Electroanal. Chem. 2001, 506, 127-137. [CrossRef]

14. Liu, J.; Fan, X.Y.; Liu, X.R.; Song, Z.S.; Deng, Y.D.; Han, X.P.; Hu, W.B.; Zhong, C. Synthesis of Cubic-Shaped Pt Particles with (100) Preferential Orientation by a Quick, One-step and Clean Electrochemical Method. ACS Appl. Mater. Interfaces 2017, 9, 18856-18864. [CrossRef] [PubMed] 
15. Adzic, R.R.; Zhang, J.; Sasaki, K.; Vukmirovic, M.B.; Shao, M.; Wang, J.X.; Nilekar, A.U.; Mavrikakis, M.; Valerio, J.A.; Uribe, F. Platinum Monolayer Fuel Cell Electrocatalysts. Top. Catal. 2007, 46, 249-262. [CrossRef]

16. Alayoglu, S.; Nilekar, A.U.; Mavrikakis, M.; Eichhorn, B. Ru-Pt Core-Shell Nanoparticles for Preferential Oxidation of Carbon Monoxide in Hydrogen. Nat. Mater. 2008, 7, 333-338. [CrossRef] [PubMed]

17. Shao, M.H.; Peles, A.; Shoemaker, K.; Gummalla, M.; Njoki, P.N.; Luo, J.; Zhong, C.J. Enhanced Oxygen Reduction Activity of Platinum Monolayer on Gold Nanoparticles. J. Phys. Chem. Lett. 2011, 2, 67-72. [CrossRef] [PubMed]

18. Liu, J.; Chen, B.; Ni, Z.; Deng, Y.; Han, X.; Hu, W.; Zhong, C. Improving the Electrocatalytic Activity of Pt Monolayer Catalysts for Electro-oxidation of Methanol, Ethanol and Ammonia by Tailoring the Surface Morphology of the Supporting Core. ChemElectroChem 2016, 3, 537-551. [CrossRef]

19. Li, M.; Liu, P.; Adzic, R.R. Platinum Monolayer Electrocatalysts for Anodic Oxidation of Alcohols. J. Phys. Chem. Lett. 2012, 3, 3480-3485. [CrossRef] [PubMed]

20. Gong, K.; Vukmirovic, M.B.; Ma, C.; Zhu, Y.M.; Adzic, R.R. Synthesis and Catalytic Activity of Pt Monolayer on Pd Tetrahedral Nanocrystals with CO-adsorption-induced Removal of Surfactants. J. Electroanal. Chem. 2011, 662, 213-218. [CrossRef]

21. Wang, J.X.; Inada, H.; Wu, L.J.; Zhu, Y.M.; Choi, Y.M.; Liu, P.; Zhou, W.P.; Adzic, R.R. Oxygen Reduction on Well-Defined Core-Shell Nanocatalysts: Particle Size, Facet, and Pt Shell Thickness Effects. J. Am. Chem. Soc. 2009, 131, 17298-17302. [CrossRef] [PubMed]

22. Shao, M.H.; Liu, P.; Zhang, J.L.; Adzic, R. Origin of Enhanced Activity in Palladium Alloy Electrocatalysts for Oxygen Reduction Reaction. J. Phys. Chem. B 2007, 111, 6772-6775. [CrossRef] [PubMed]

23. Sasaki, K.; Naohara, H.; Choi, Y.; Cai, Y.; Chen, W.F.; Liu, P.; Adzic, R.R. Highly Stable Pt Monolayer on PdAu Nanoparticle Electrocatalysts for the Oxygen Reduction Reaction. Nat. Commun. 2012, 3, 1115. [CrossRef] [PubMed]

24. Kuttiyiel, K.A.; Sasaki, K.; Choi, Y.; Su, D.; Liu, P.; Adzic, R.R. Bimetallic IrNi Core Platinum Monolayer Shell Electrocatalysts for the Oxygen Reduction Reaction. Energy Environ. Sci. 2012, 5, 5297-5304. [CrossRef]

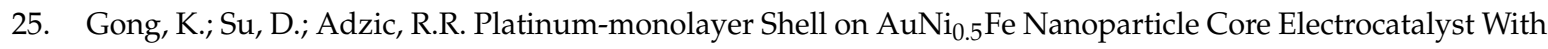
High Activity and Stability for the Oxygen Reduction Reaction. J. Am. Chem. Soc. 2010, 132, 14364-14366. [CrossRef] [PubMed]

26. Brankovic, S.R.; Wang, J.X.; Adžić, R.R. Metal Monolayer Deposition by Replacement of Metal Adlayers on Electrode Surfaces. Surf. Sci. 2001, 474, L173-L179. [CrossRef]

27. Sasaki, K.; Wang, J.X.; Naohara, H.; Marinkovic, N.; More, K.; Inada, H.; Adzic, R.R. Recent Advances in Platinum Monolayer Electrocatalysts for Oxygen Reduction Reaction: Scale-up Synthesis, Structure and Activity of Pt Shells on Pd Cores. Electrochim. Acta 2010, 55, 2645-2652. [CrossRef]

28. Shao, M.H.; He, G.N.; Peles, A.; Odell, J.H.; Zeng, J.; Su, D.; Tao, J.; Yu, T.; Zhu, Y.; Xia, Y.N. Manipulating the Oxygen Reduction Activity of Platinum Shells with Shape-controlled Palladium Nanocrystal Cores. Chem. Commun. 2013, 49, 9030-9032. [CrossRef]

29. Wang, X.M.; Orikasa, Y.; Takesue, Y.; Inoue, H.; Nakamura, M.; Minato, T.; Hoshi, N.; Uchimoto, Y. Quantitating the Lattice Strain Dependence of Monolayer Pt Shell Activity Toward Oxygen Reduction. J. Am. Chem. Soc. 2013, 135, 5938-5941. [CrossRef]

30. Zhang, J.; Lima, F.H.B.; Shao, M.H.; Sasaki, K.; Wang, J.X.; Hanson, J.; Adzic, R.R. Platinum Monolayer on Nonnoble Metal-noble Metal Core-Shell Nanoparticle Electrocatalysts for $\mathrm{O}_{2}$ Reduction. J. Phys. Chem. B 2005, 109, 22701-22704. [CrossRef]

31. Zhang, J.L.; Vukmirovic, M.B.; Xu, Y.; Mavrikakis, M.; Adzic, R.R. Controlling the Catalytic Activity of Platinum-monolayer Electrocatalysts for Oxygen Reduction with Different Substrates. Angew. Chem. Int. Ed. 2005, 117, 2170-2173. [CrossRef]

32. Ni, Z.Y.; Liu, J.; Wu, Y.T.; Liu, B.; Zhao, C.K.; Deng, Y.D.; Hu, W.B.; Zhong, C. Fabrication of Platinum Submonolayer Electrodes and Their High Electrocatalytic Activities for Ammonia Oxidation. Electrochim. Acta 2015, 177, 30-35. [CrossRef]

33. Yu, Y.L.; Hu, Y.P.; Liu, X.W.; Deng, W.Q.; Wang, X. The Study of Pt@Au Electrocatalyst Based on Cu Underpotential Deposition and Pt Redox Replacement. Electrochim. Acta 2009, 54, 3092-3097. [CrossRef]

34. Oppedisano, D.K.; Jones, L.A.; Junk, T.; Bhargava, S.K. Ruthenium Electrodeposition from Aqueous Solution at High Cathodic Overpotential. J. Electrochem. Soc. 2014, 161, D489-D494. [CrossRef] 
35. Le Vot, S.; Roué, L.; Bélanger, D. Electrodeposition of Iridium onto Glassy Carbon and Platinum Electrodes. Electrochim. Acta 2012, 59, 49-56. [CrossRef]

36. Vidal-Iglesias, F.J.; Solla-Gullón, J.; Montiel, V.; Feliu, J.M.; Aldaz, A. Screening of Electrocatalysts for Direct Ammonia Fuel Cell: Ammonia Oxidation on PtMe (Me: Ir, Rh, Pd, Ru) and Preferentially Oriented Pt(100) Nanoparticles. J. Power Sources 2007, 171, 448-456. [CrossRef]

37. Yao, K.; Cheng, Y.F. Electrodeposited Ni-Pt Binary Alloys as Electrocatalysts for Oxidation of Ammonia. J. Power Sources 2007, 173, 96-101. [CrossRef]

38. Deng, X.H.; Wu, Y.T.; He, M.F.; Dan, C.Y.; Chen, Y.J.; Deng, Y.D.; Jiang, D.H.; Zhong, C. Electrochemical Deposition of Pt Particles on Indium Tin Oxide Electrode and Their Electrocatalytic Applications in Ammonia Oxidation. Acta Chim. Sin. 2011, 69, 1041-1046. (In Chinese)

39. Cooper, M.; Botte, G.G. Hydrogen Production from the Electro-oxidation of Ammonia Catalyzed by Platinum and Rhodium on Raney Nickel Substrate. J. Electrochem. Soc. 2006, 153, A1894. [CrossRef]

40. Kazemi, R.; Kiani, A. Deposition of Palladium Submonolayer on Nanoporous Gold Film and Investigation of Its Performance for the Methanol Electrooxidation Reaction. Int. J. Hydrogen Energy 2012, 37, 4098-4106. [CrossRef]

41. Santos, M.C.; Mascaro, L.H.; Machado, S.A.S. Voltammetric and Rotating Ring-disk Studies of Underpotential Deposition of $\mathrm{Ag}$ and $\mathrm{Cu}$ on Polycrystalline Au Electrodes in Aqueous $\mathrm{H}_{2} \mathrm{SO}_{4}$. Electrochim. Acta 1998, 43, 2263-2272. [CrossRef]

42. Markovic, N.M.; Gasteiger, H.A.; Ross, P.N.J. Copper Electrodeposition on Pt (111) in the Presence of Chloride and (bi) Sulfate: Rotating Ring-Pt (111) Disk Electrode Studies. Langmuir 1995, 11, 4098-4108. [CrossRef]

43. Markovíc, N.M.; Ross, P.N., Jr. Surface Science Studies of Model Fuel Cell Electrocatalysts. Surf. Sci. Rep. 2002, 45, 117-229. [CrossRef]

44. Zhong, C.; Hu, W.B.; Cheng, Y.F. On the Essential Role of Current Density in Electrocatalytic Activity of The Electrodeposited Platinum for Oxidation of Ammonia. J. Power Sources 2011, 196, 8064-8072. [CrossRef]

45. Liu, J.; Hu, W.B.; Zhong, C.; Cheng, Y.F. Surfactant-free Electrochemical Synthesis of Hierarchical Platinum Particle Electrocatalysts for Oxidation of Ammonia. J. Power Sources 2013, 223, 165-174. [CrossRef]

46. Liu, P.; Ge, X.; Wang, R.; Ma, H.; Ding, Y. Facile Fabrication of Ultrathin Pt Overlayers onto Nanoporous Metal Membranes via Repeated Cu UPD and In situ Redox Replacement Reaction. Langmuir 2009, 25, 561-567. [CrossRef] [PubMed]

47. Hu, J.; Kuttiyiel, K.A.; Sasaki, K.; Su, D.; Yang, T.H.; Park, G.G.; Zhang, C.; Chen, G.; Adzic, R.R. Pt Monolayer Shell on Nitrided Alloy Core-A Path to Highly Stable Oxygen Reduction Catalyst. Catalysts 2015, 5, 1321-1332. [CrossRef]

48. Kuttiyiel, K.A.; Sasaki, K.; Su, D.; Vukmirovic, M.B.; Marinkovic, N.S.; Adzic, R.R. Pt Monolayer on Au-stabilized PdNi Core-Shell Nanoparticles for Oxygen Reduction Reaction. Electrochim. Acta 2013, 110, 267-272. [CrossRef]

49. Choi, Y.; Kuttiyiel, K.A.; Labis, J.P.; Sasaki, K.; Park, G.G.; Yang, T.H.; Adzic, R.R. Enhanced Oxygen Reduction Activity of IrCu Core Platinum Monolayer Shell Nano-Electrocatalysts. Top. Catal. 2013, 56, 1059-1064. [CrossRef]

50. Lee, E.P.; Peng, Z.; Cate, D.M.; Yang, H.; Campbell, C.T.; Xia, Y. Growing Pt Nanowires as a Densely Packed Array on Metal Gauze. J. Am. Chem. Soc. 2007, 129, 10634-10635. [CrossRef]

51. Lim, B.; Jiang, M.; Camargo, P.H.; Cho, E.C.; Tao, J.; Lu, X.; Zhu, Y.; Xia, Y. Pd-Pt Bimetallic Nanodendrites with High Activity for Oxygen Reduction. Science 2009, 324, 1302-1305. [CrossRef] [PubMed]

52. Liu, J.; Du, X.T.; Yang, Y.; Deng, Y.D.; Hu, W.B.; Zhong, C. A One-step, Clean, Capping-agent-free Electrochemical Approach to Prepare Pt nanoparticles with Preferential (100) Orientation and Their High Electrocatalytic Activities. Electrochem. Commun. 2015, 58, 6-10. [CrossRef]

53. Wu, S.; Liu, J.; Tian, Z.; Cai, Y.; Ye, Y.; Yuan, Q.; Liang, C. Highly Dispersed Ultrafine Pt Nanoparticles on Reduced Graphene Oxide Nanosheets: In Situ Sacrificial Template Synthesis and Superior Electrocatalytic Performance for Methanol Oxidation. ACS Appl. Mater. Interfaces 2015, 7, 22935-22940. [CrossRef] [PubMed]

54. Gerischer, H.; Mauerer, A. Untersuchungen Zur Anodischen Oxidation Von Ammoniak an Platin-elektroden. J. Electroanal. Chem. 1970, 25, 421-433. [CrossRef]

55. Vidaliglesias, F.; Sollagullon, J.; Perez, J.; Aldaz, A. Evidence by SERS of Azide Anion Participation in Ammonia Electrooxidation in Alkaline Medium on Nanostructured Pt Electrodes. Electrochem. Commun. 2006, 8, 102-106. [CrossRef] 
56. Rosca, V.; Koper, M.T. Electrocatalytic Oxidation of Ammonia on $\operatorname{Pt}(111)$ and $\operatorname{Pt}(100)$ Surfaces. Phys. Chem. Chem. Phys. 2006, 8, 2513-2524. [CrossRef] [PubMed]

57. Novell-Leruth, G.; Valcárcel, A.; Clotet, A.; Ricart, J.M.; Pérez-Ramírez, J. DFT Characterization of Adsorbed $\mathrm{NH}_{x}$ Species on Pt(100) and Pt(111) Surfaces. J. Phys. Chem. B 2005, 109, 18061-18069. [CrossRef] [PubMed]

58. Hammer, B.; Nørskov, J.K. Theoretical Surface Science and Catalysis-Calculations and Concepts. Adv. Catal. 2000, 45, 71-129.

59. Greeley, J.; Nørskov, J.K.; Mavrikakis, M. Electronic Structure and Catalysis on Metal Surfaces. Annu. Rev. Phys. Chem. 2002, 53, 319-348. [CrossRef]

60. Endo, K.; Katayama, Y.; Miura, T. Pt-Ir and Pt-Cu Binary Alloys as the Electrocatalyst for Ammonia Oxidation. Electrochim. Acta 2004, 49, 1635-1638. [CrossRef]

61. Zhong, C.; Liu, J.; Ni, Z.Y.; Deng, Y.D.; Chen, B.; Hu, W.B. Shape-controlled Synthesis of Pt-Ir Nanocubes with Preferential (100) Orientation and Their Unusual Enhanced Electrocatalytic Activities. Sci. China Mater. 2014, 57, 13-25. [CrossRef]

62. Endo, K.; Nakamura, K.; Katayama, Y.; Miura, T. Pt-Me (Me = Ir, Ru, Ni) binary alloys as an ammonia oxidation anode. Electrochim. Acta 2004, 49, 2503-2509. [CrossRef]

63. Vidal-Iglesias, F.J.; Solla-Gullón, J.; Rodríguez, P.; Herrero, E.; Montiel, V.; Feliu, J.M.; Aldaz, A. Shape-dependent electrocatalysis: Ammonia oxidation on platinum nanoparticles with preferential (100) surfaces. Electrochem. Commun. 2004, 6, 1080-1084. [CrossRef]

64. Vidal-Iglesias, F.J.; García-Aráez, N.; Montiel, V.; Feliu, J.M.; Aldaz, A. Selective electrocatalysis of ammonia oxidation on $\mathrm{Pt}(100)$ sites in alkaline medium. Electrochem. Commun. 2003, 5, 22-26. [CrossRef]

65. Bertin, E.; Garbarino, S.; Guay, D.; Solla-Gullón, J.; Vidal-Iglesias, F.J.; Feliu, J.M. Electrodeposited Platinum Thin Films with Preferential (100) Orientation: Characterization and Electrocatalytic Properties for Ammonia and Formic Acid Oxidation. J. Power Sources 2013, 225, 323-329. [CrossRef]

66. Ojani, R.; Hasheminejad, E.; Raoof, J.B. Direct growth of 3D flower-like Pt nanostructures by a template-free electrochemical route as an efficient electrocatalyst for methanol oxidation reaction. Energy 2015, 90, 1122-1131. [CrossRef]

67. Li, C.A.; Han, K.N.; Bui, M.P.N.; Pham, X.H.; Hong, M.H.; Irfan, M.; Kim, Y.S.; Seong, G.H. Morphology-controlled synthesis and electrocatalytic characteristics of platinum structures on micro-patterned carbon nanotube platforms. J. Appl. Electrochem. 2011, 41, 1425-1431. [CrossRef]

68. El-Nagar, G.A.; Mohammad, A.M.; El-Deab, M.S.; El-Anadouli, B.E. Electrocatalysis by design: Enhanced electrooxidation of formic acid at platinum nanoparticles-nickel oxide nanoparticles binary catalysts. Electrochim. Acta 2013, 94, 62-71. [CrossRef] 